\title{
Long Runs and Higher Incidence of Bleeding Complications in COVID-19 Patients Requiring Venovenous Extracorporeal Membrane Oxygenation: A Case Series from the United Arab Emirates
}

\author{
Vivek Kakar ${ }^{1} \odot$, Anita North ${ }^{\odot}$, Gurjyot Bajwa ${ }^{3} \odot$, Nuno Raposo ${ }^{4} \odot$, Praveen Kumar $\mathrm{G}^{5} \odot$
}

\begin{abstract}
Although the pathophysiology of pulmonary disease caused by coronavirus disease-2019 (COVID-19) is not yet fully understood, successful extracorporeal membrane oxygenation (ECMO) use has been reported for COVID-19-related severe acute respiratory distress syndrome (ARDS). We report a case series of 12 patients who received long venovenous ECMO (VV ECMO) runs for refractory hypoxia (median PF ratio of 71.8, interquartile range (IQR) 53.5-78.5) from COVID-19-related ARDS. A majority (75\%) of the patients were males with a median age of 44 (IQR 37-53.5). Overall, six (50\%) patients survived to hospital discharge with five of them (83.3\%) noted to be cerebral performance category 1 or 2 at the time of discharge. Survivors consistently showed an improvement in sequential organ failure assessment scores within 72 hours of ECMO initiation. The median ECMO duration was 28 days (IQR 13.5-50). Despite using standard anticoagulation strategy, six (50\%) of our patients had one or more major bleeding episodes, which proved to be directly fatal in four (25\%) patients. Although the overall outcomes of our cohort were acceptable, our patients had much longer ECMO runs (mean 38 days in survivors) and with much higher, often fatal bleeding complications. We compare our data with other published COVID-19 VV ECMO series.
\end{abstract}

Keywords: Acute respiratory distress syndrome, COVID-19, Extracorporeal membrane oxygenation, SARS-CoV-2.

Indian Journal of Critical Care Medicine (2021): 10.5005/jp-journals-10071-24054

\section{Highlights}

- Venovenous extracorporeal membrane oxygenation is an effective life-saving rescue strategy for patients with refractory ARDS from COVID-19 but survivors should expect to be on ECMO and in hospital for a long duration along with a higher incidence of major and potentially fatal bleeding complications.

- Optimum patient selection criteria and timing of ECMO initiation as well as appropriate anticoagulation strategy need further research.

\section{INTRODUCTION}

Although majority of coronavirus disease-2019 (COVID-19)-related acute respiratory distress syndrome (ARDS) meets the Berlin definition, ${ }^{1}$ its pathophysiological and radiological features suggest it is not a typical ARDS. ${ }^{2}$ The underlying pathogenesis, understanding of which is still evolving, associated cytokine storm, and significant extrapulmonary manifestations make it a distinct multisystem disease. ${ }^{3}$ Some of the established ARDS strategies, such as prone positioning and high positive end-expiratory pressure (PEEP) also seem to be effective in COVID-19 related ARDS. ${ }^{4,5}$ A substantial proportion, up to $17 \%$ in a large single-center series, goes on to develop refractory hypoxemia requiring venovenous extracorporeal membrane oxygenation (VV ECMO). ${ }^{6}$ Several centers have reported their VV ECMO experiences but with variable patient selection and outcomes. ${ }^{7-10}$ The management of these patients has also been marred with confusion regarding appropriate anticoagulation
${ }^{1,2,5}$ Critical Care Institute, Cleveland Clinic Abu Dhabi, Abu Dhabi, United Arab Emirates

${ }^{3,4}$ Department of Cardiac Surgery, Cleveland Clinic Abu Dhabi, Abu Dhabi, United Arab Emirates

Corresponding Author: Vivek Kakar, Critical Care Institute, Cleveland Clinic Abu Dhabi, Abu Dhabi, United Arab Emirates, Phone: +971-555675897, e-mail:v.kakar@gmail.com

How to cite this article: Kakar V, North A, Bajwa G, Raposo N, Kumar PG. Long Runs and Higher Incidence of Bleeding Complications in COVID-19 Patients Requiring Venovenous Extracorporeal Membrane Oxygenation: A Case Series from the United Arab Emirates. Indian J Crit Care Med 2021;25(12):1452-1458.

Source of support: Nil

Conflict of interest: None

strategy with numerous reports of COVID associated coagulopathy resulting in a higher incidence of pulmonary thromboembolism. ${ }^{11}$ While a need for higher dose chemical thromboprophylaxis has been recognized, the guidelines differ considerably on the specifics. ${ }^{11}$ However, more recent data from the Inspiration trial do not support a higher dose chemoprophylaxis as a first-line strategy. ${ }^{12}$ Aggravating the confusion, a large number of case reports of major bleeding complications in COVID-19 patients, independent of chemoprophylactic strategy have now been reported. ${ }^{13-15}$

We present below our case series of 12 patients from the Cleveland Clinic Abu Dhabi, a tertiary referral center in the UAE.

(c) The Author(s). 2021 Open Access This article is distributed under the terms of the Creative Commons Attribution 4.0 International License (https://creativecommons. org/licenses/by-nc/4.0/), which permits unrestricted use, distribution, and non-commercial reproduction in any medium, provided you give appropriate credit to the original author(s) and the source, provide a link to the Creative Commons license, and indicate if changes were made. The Creative Commons Public Domain Dedication waiver (http://creativecommons.org/publicdomain/zero/1.0/) applies to the data made available in this article, unless otherwise stated. 


\section{Case Description}

Cleveland Clinic Abu Dhabi is the only Extracorporeal Life Support Organization (ELSO) registered ECMO center in the United Arab Emirates. A total of 17 COVID-19 patients received ECMO at our institute between April and October 2020. Five patients who received venoarterial ECMO (VA ECMO) or hybrid ECMO configurations, or are still in the ICU, were excluded from the current report that describes only the VV ECMO patients who have been discharged from the hospital. All patients were cannulated percutaneously at the bedside with ultrasound guidance in a femoral-jugular configuration. Four patients were retrieved after cannulation by our team at the referring hospitals. Specific protocols for the management of ARDS and VV ECMO in COVID-19 patients were prepared and approved in advance of the pandemic peak in the UAE. For all patients who were admitted to our unit before ECMO initiation, ECMO to rescue Lung Injury in severe ARDS trial (EOLIA) criteria were used for patient selection ${ }^{16}$ and ELSO definitions were used to classify any observed complications. ${ }^{17}$ Prior to ECMO initiation, confirmed COVID-19 patients at our institution received higher dose chemical thromboprophylaxis based on their D-dimer levels. However, once on ECMO, we decided to adopt our standard anticoagulation regime using an infusion of unfractionated Heparin, targeting an activated partial thromboplastin time (apTT) of 40-60 seconds. All data after the patient arrived at our facility were collected prospectively until death or hospital discharge with 90-day outcomes confirmed with telephone calls.

The median age was 44 (IQR $37-53.5$ ) and $75 \%$ of patients were males. Four patients were from India, three from the UAE, two from Pakistan, one each from Nepal, Uganda, and Palestine. This demographic spread represents the extremely diverse ethnic composition of the UAE population with a predominance of people from the Indian subcontinent. One patient had previously undiagnosed polycystic kidney disease, one had bronchial asthma, four had poorly controlled type II diabetes mellitus, and five had essential hypertension. Seven patients were overweight (BMI 25-30) and only one patient was morbidly obese (BMI 55). Indication for ECMO initiation was refractory hypoxia in all cases with a median PF ratio of 71.8 (IQR 53.7-78.5). In addition, four patients (25\%) also had uncompensated hypercapnic acidosis with $\mathrm{pH}<7.2$.

Table 1 summarizes the overall clinical course of these patients. While seven patients (58.3\%) were alive at 90 days, only six patients
(50\%) survived to hospital discharge. Five out of these six discharged patients $(83.3 \%)$ were classified as either cerebral performance category 1 or 2 at hospital discharge. The duration between symptom onset and intubation and between intubation and ECMO had no bearing on survival or the duration of ECMO required. Table 2 shows the respiratory and COVID-19 specific management. All our patients received tocilizumab but only seven (56\%) received steroids, including three who received it primarily for septic shock. Table 3 shows characteristics relating to ECMO and its complications. All our patients had Murray's lung injury score of 3.5-4 at ECMO initiation and six (50\%) were in shock requiring pressors. Survivors were consistently noted to show a significant improvement in sequential organ failure assessment (SOFA) score (delta SOFA) within 72 hours of ECMO initiation. Eleven (91.7\%) patients had some form of minor bleeding while there were 11 episodes of major bleeding

Table 2: Respiratory and COVID-19 management

\begin{tabular}{lc}
\hline Management strategy & $\begin{array}{c}N=12, \text { data as a proportion } \\
(\%) \text { or median with IQR }\end{array}$ \\
\hline Respiratory management, & \\
preintubation & $10(83.3 \%)$ \\
High-flow nasal cannula & $11(91.7 \%)$ \\
Non-invasive ventilation (NIV) & $10(83.3 \%)$ \\
Prone positioning (awake, self) & \\
Ventilatory management, & \\
postintubation & \\
Ventilator mode & Pressure control (7), volume \\
& control (2), Pressure regulated \\
& volume control (PRVC) (3) \\
PEEP & $14(12-15)$ \\
Neuromuscular paralysis & $12(100 \%)$ \\
Prone positioning & $11(91.7 \%)$ \\
Prone positioning hours & $62(28-80)$ \\
Inhaled nitric oxide & $7(58.3 \%)$ \\
Barotrauma (pneumothorax) & $6(50 \%)$ \\
Ventilatory management, on ECMO & \\
Lung rest & $12(100 \%)$ \\
Prone positioning & $2(16.7 \%)$ \\
Extubated on ECMO & $2(16.7 \%)$ \\
Tracheostomy & $10(83.3 \%)$ \\
\hline
\end{tabular}

Table 1: Overall clinical course and outcomes

\begin{tabular}{|c|c|c|c|c|c|c|c|c|c|}
\hline \multirow[b]{2}{*}{$\begin{array}{l}\text { Case } \\
\text { No. }\end{array}$} & \multirow[b]{2}{*}{ Age/sex } & \multicolumn{3}{|c|}{ Duration (days) } & \multicolumn{3}{|c|}{ Outcomes } & \multicolumn{2}{|c|}{ LOS (days) } \\
\hline & & $\begin{array}{l}\text { Symptoms to } \\
\text { intubation }\end{array}$ & $\begin{array}{l}\text { Intubation } \\
\text { to ECMO }\end{array}$ & $\begin{array}{c}\text { ECMO to } \\
\text { wean/death }\end{array}$ & $I C U$ & $\begin{array}{l}\text { Hospital } \\
\text { (CPC) }\end{array}$ & 90-day & $I C U$ & Hospital \\
\hline 1 & $36 / M$ & 8 & 3 & 4 (death) & Dead & Dead (5) & Dead & 8 & 12 \\
\hline 2 & $38 / \mathrm{M}$ & 10 & 6 & 73 (wean) & Alive & Alive (2) & Alive & 98 & 147 \\
\hline 3 & $42 / M$ & 7 & 1 & 34 (wean) & Alive & Alive (1) & Alive & 73 & 90 \\
\hline 4 & $50 / F$ & 9 & 2 & 9 (death) & Dead & Dead (5) & Dead & 16 & 16 \\
\hline 5 & $46 / M$ & 8 & 10 & 27 (death) & Dead & Dead (5) & Dead & 42 & 42 \\
\hline 6 & $54 / \mathrm{M}$ & 8 & 8 & 42 (wean) & Alive & Alive (3) & Alive & 59 & 137 \\
\hline 7 & $42 / M$ & 3 & 2 & 66 (wean) & Alive & Alive (2) & Alive & 94 & 104 \\
\hline 8 & $53 / M$ & 19 & 1 & 18 (death) & Dead & Dead (5) & Dead & 25 & 27 \\
\hline 9 & $35 / M$ & 12 & 2 & 31 (death) & Dead & Dead (5) & Dead & 38 & 44 \\
\hline 10 & $60 / M$ & 12 & 5 & 15 (wean) & Alive & Alive (1) & Alive & 38 & 55 \\
\hline 11 & $60 / F$ & 11 & 9 & 92 (death) & Dead & Dead (5) & Alive & 107 & 107 \\
\hline 12 & $25 / F$ & 21 & 6 & 11 (wean) & Alive & Alive (1) & Alive & 23 & 36 \\
\hline
\end{tabular}

$M$, male; $F$, female; ICU, intensive care unit; CPC, cerebral performance category; LOS, length of stay 
Table 3: ECMO characteristics

\begin{tabular}{|c|c|}
\hline Characteristic & $N=12$, data as a proportion (\%) or median with IQR \\
\hline \multicolumn{2}{|l|}{ Severity } \\
\hline PF ratio & $71.5(53.5-78.5)$ \\
\hline Respiratory ECMO survival prediction (RESP) & $3(2-4.5)$ \\
\hline Murrays'lung injury score & $3.8(3.5-3.9)$ \\
\hline SOFA at ECMO initiation & $6(5-8)$ \\
\hline SOFA at 72 hours & $4.5(3-7.5)$ \\
\hline Delta SOFA at 72 hours & $\begin{array}{l}\text { Survivors: median }-2.5(-3 \text { to }-2) \text {, mean }-2.5 \\
\text { Nonsurvivors: median } 0(0-1) \text {, mean } 0.167 \\
p \text {-value } 0.0057(<0.05)\end{array}$ \\
\hline Shock (needing pressors) & $6(50 \%)$ \\
\hline Lactate & $1.87(1.36-2.33)$ \\
\hline Symptom onset to ECMO, days & Mean $15 \pm 3.378$, median $15(11.5-19)$ \\
\hline Survivors & Mean $14.17 \pm 6.227$, median $14(8-17)$ \\
\hline Nonsurvivors & $\begin{array}{l}\text { Mean } 15.83 \pm 3.217, \text { median } 16(12-20) \\
p=0.32(>0.05)\end{array}$ \\
\hline Intubation to ECMO, days & Mean $4.5 \pm 1.765$, median $4(2-6.5)$ \\
\hline Survivors & Mean $4.5 \pm 1.944$, median $2.5(2-9)$ \\
\hline Nonsurvivors & $\begin{array}{l}4.5 \pm 3.15(\text { mean }), \text { median } 5.5(2-6) \\
p=0.5(>0.05)\end{array}$ \\
\hline \multicolumn{2}{|l|}{ ECMO cannulation } \\
\hline Configuration & Femoral-Jugular (100\%) \\
\hline Cannulae & $25 / 19 \operatorname{Fr}(8), 29 / 19 \operatorname{Fr}(1), 23 / 19 \operatorname{Fr}(2), 25 / 17 \operatorname{Fr}(1)$ \\
\hline Need for VVV & $2(20 \%)$ \\
\hline \multicolumn{2}{|l|}{ ECMO complications } \\
\hline Minor bleeding & 11 (91.7\%)—cannulation sites, oropharyngeal, Upper Gl \\
\hline \multicolumn{2}{|r|}{ 年 } \\
\hline Intracranial hemorrhage(s) & $4(33.3 \%)$ total \\
\hline & $3(25 \%)$ on ECMO \\
\hline & 1 (8.3\%) developed ICH 2 weeks after ICU Discharge \\
\hline Pulmonary hemorrhage & $2(16.7 \%)$ - both needed embolization \\
\hline Hemothorax & $\begin{array}{l}2(16.7 \%)-1 \text { needed video-assisted thoracoscopic surgery } \\
\text { (VATS) procedure and decortication }\end{array}$ \\
\hline Pericardial tamponade & $1(8.3 \%)$ \\
\hline Psoas hematoma & $1(8.3 \%)$ \\
\hline Tracheal hemorrhage & $1(8.3 \%)$ \\
\hline \multicolumn{2}{|l|}{ Transfusions (units) } \\
\hline Packed red blood cells (PRBC) & $17.5(7-27)$ \\
\hline Platelets & $0(0-2)$ \\
\hline Fresh frozen plasma (FFP) & $0(0-1.5)$ \\
\hline Oxygenator failure/change & $5(41.7 \%)$ \\
\hline Massive pulmonary embolism & $2(16.7 \%)$ \\
\hline ECMO duration, days & Mean $34.25 \pm 16.087$, median $28(13.5-50)$ \\
\hline Survivors & Mean $38.5 \pm 20.486$, median $32.5(15-66)$ \\
\hline Nonsurvivors & $\begin{array}{l}\text { Mean } 30 \pm 26.29, \text { median } 21.5(9-30) \\
p=0.31(>0.05)\end{array}$ \\
\hline ICU length of stay, days & Mean $48.83 \pm 19$, median $36(23-79.5)$ \\
\hline Survivors & Mean $59.17 \pm 23.44$, median $62.5(28-88)$ \\
\hline Nonsurvivors & $\begin{array}{l}\text { Mean } 36.17 \pm 36.17, \text { median } 26.5(15-32) \\
p=0.131(>0.05)\end{array}$ \\
\hline Hospital length of stay, days & Mean $65.58 \pm 26.78$, median $47.5(27.5-106)$ \\
\hline Survivors & Mean $92.83 \pm 33.25$, median $93(53-133)$ \\
\hline Nonsurvivors & $\begin{array}{l}\text { Mean } 38.33 \pm 30.14, \text { median } 27.5(15-42) \\
p=0.019(<0.05)\end{array}$ \\
\hline
\end{tabular}

in six patients, including four (25\%) intracranial hemorrhages (ICH) (Fig. 1). One patient had psoas hematoma and one patient developed bronchial hemorrhage (Fig. 2). Three patients with ICH progressed to brain death and one bronchial hemorrhage also proved to be fatal. Five patients (41.7\%) required more than one oxygenator. The duration of ECMO was very long in our series, with a median of 28 days overall (IQR 13.5-50), even longer in the survivors where the median duration was 32.5 days (IQR 15-66).

\section{Discussion}

In this small series of 12 patients requiring VV ECMO for refractory COVID related ARDS, $50 \%$ of patients survived to hospital discharge 

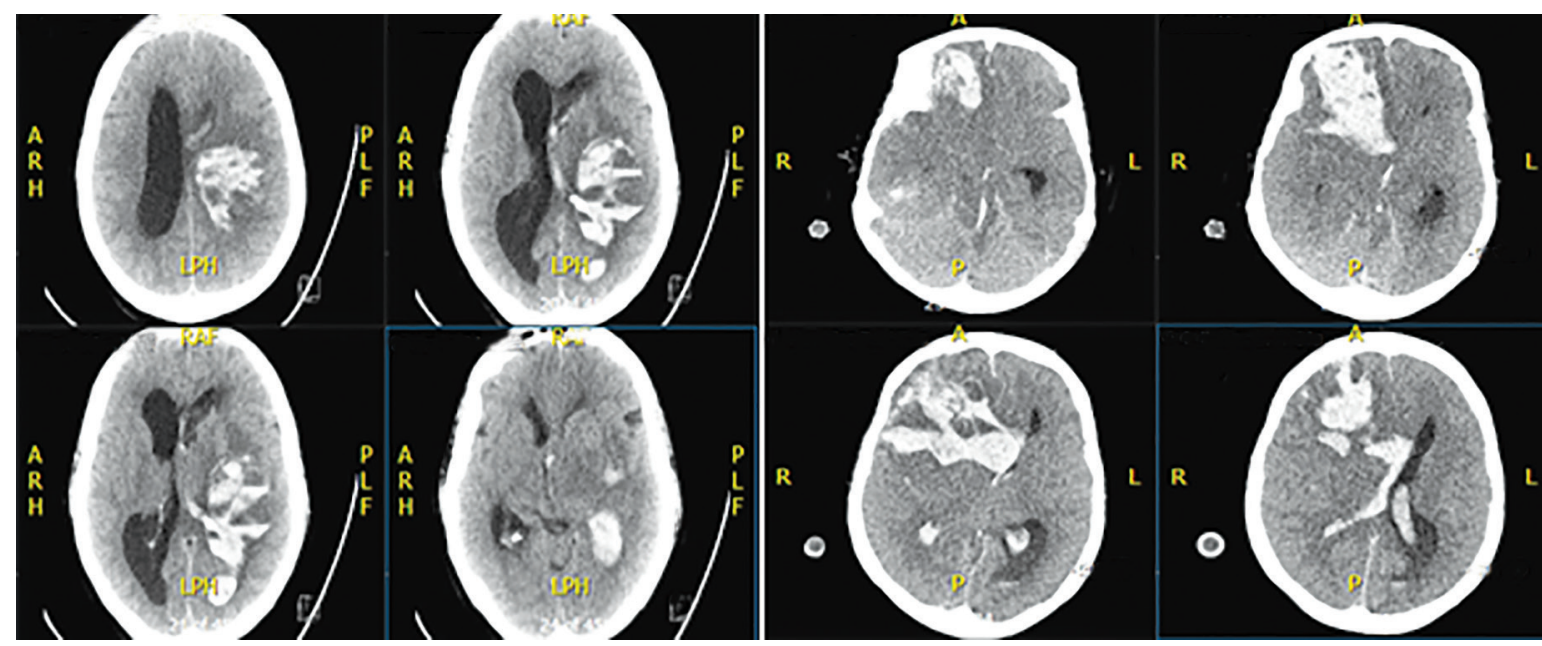

Fig. 1: Intracranial hemorrhages (clockwise from top left, patients 1-4)
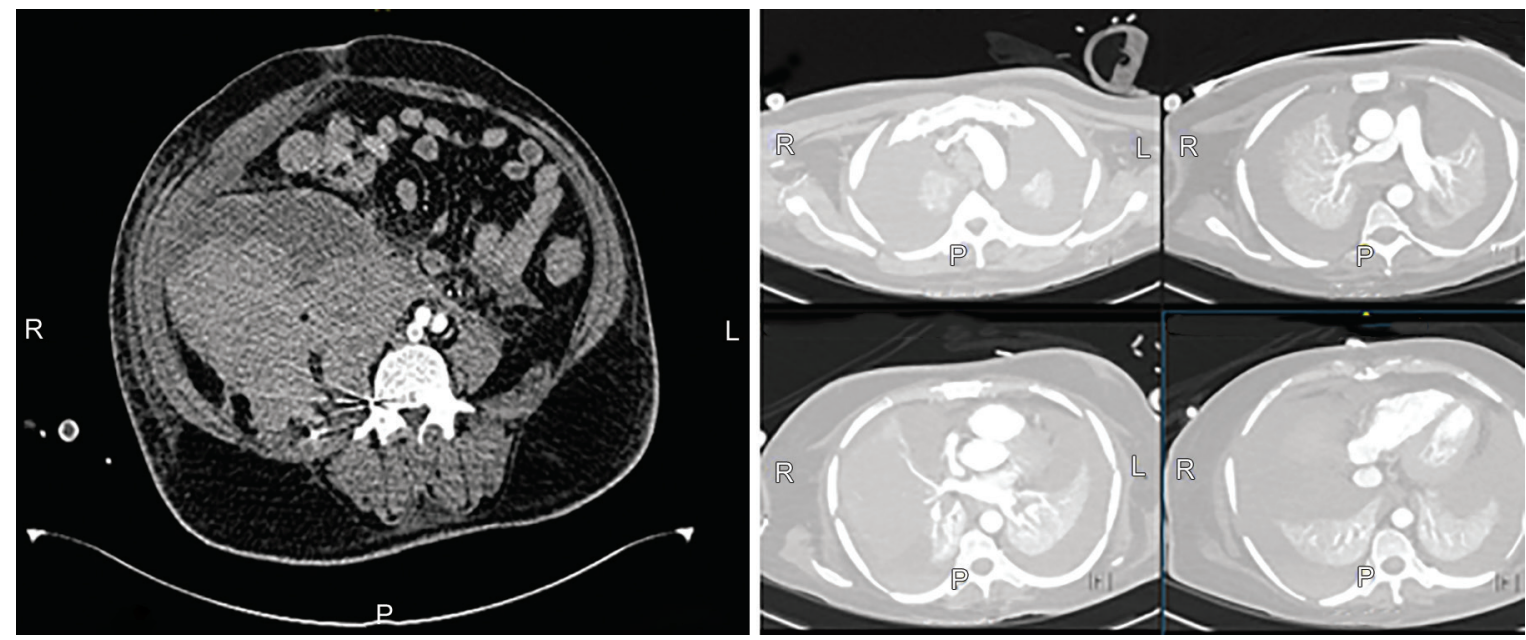

Fig. 2: Nonneurological bleeding complications (left: retroperitoneal hematoma; right: refractory bronchial hemorrhage with complete airway obstruction)

with a majority of them in good functional status at the time of discharge. The most recently updated ELSO COVID dashboard also reveals only a $49 \%$ inhospital survival in 5,608 patients who have received ECMO for COVID-19 in ELSO registered centers worldwide. ${ }^{18}$ However, several others have reported their experience with ECMO for this condition with better outcomes. In the French series of 83 patients ${ }^{6}$ where EOLIA criteria were used for ECMO initiation, a $69 \%$ survival rate at 60 days post-ECMO was reported, while a group from Chicago reported $85 \%$ survival using the same criteria in their series of 40 patients. ${ }^{19}$ Earlier, ELSO also published outcomes in 978 COVID-19 patients who received VV ECMO for refractory ARDS, reporting an overall hospital survival of $63 \%{ }^{7}$

We would like to highlight some observations from our series and list some limitations. First, our series is too small to make any meaningful comparisons with other much larger series. Second, most of the patients were transferred to us from other much smaller hospitals where the ARDS management they received was not standardized and often not evidence-based. Third, most of our patients came from a lower socioeconomic class with no previous health screening as evident from the poor baseline control or knowledge of their comorbidities. Fourth, as suggested previously, many patients were referred to the institute late in the course of the disease and the team had no control over the management of patients before being referred to. Also, since the previously published literature does not support the use of steroids in viral pneumonias ${ }^{20,21}$ and patients received ECMO prior to the publication of the Recovery trial, ${ }^{22}$ not all patients received steroids. It is plausible that these factors could have had an impact on survival as well as the duration of ECMO.

Fifth, our patients had a much higher incidence of bleeding complications than any of the other reported series. In the French series reported above, the incidence of major bleeding was $42 \%$ but only four (5\%) had hemorrhagic stroke despite using a higher than usual apTT target for anticoagulation in their cohort. ${ }^{23}$ In another series of 43 patients from the United Kingdom, only $18.6 \%$ of patients had major bleeding and no ICH were observed. ${ }^{24}$ Risk factors previously identified with a higher incidence of ICH in ECMO patients include female sex, thrombocytopenia, renal failure, and a sudden drop in $\mathrm{PCO}_{2}$ after ECMO initiation. ${ }^{25-27}$ None of our patients with $\mathrm{ICH}$ had these risk factors noted around the time of bleeding (Figure 3). Also, no correlation was noted between the duration of ECMO and risk of bleeding. Our demographic while different from 

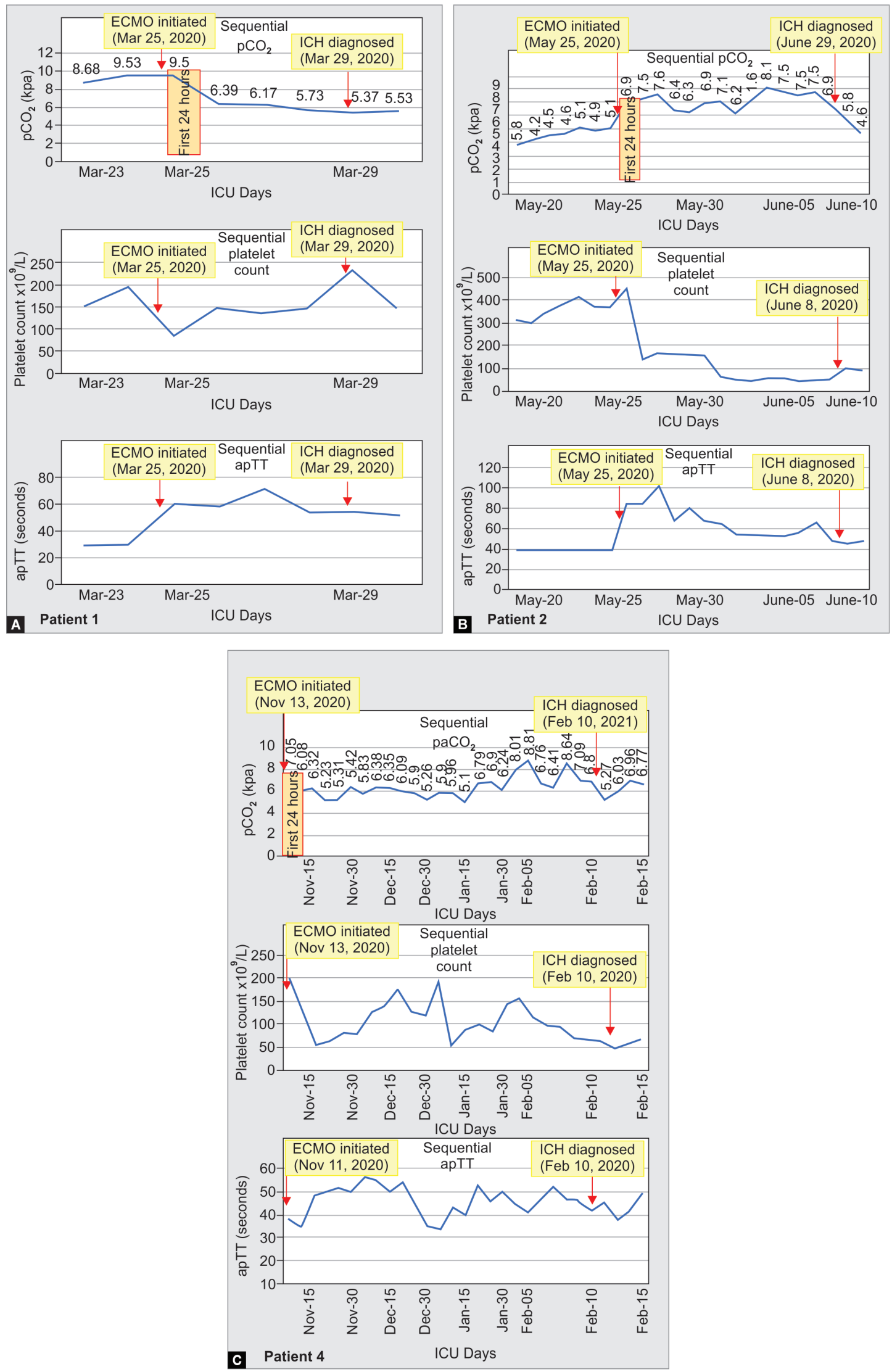

Figs $3 \mathrm{~A}$ to $\mathrm{C}$ : Sequential $\mathrm{pCO}_{2}$, platelet count, and apTT of three patients who had ICH while on ECMO ( $\mathrm{pCO}_{2}$, partial pressure of carbon dioxide, apTT, activated partial thromboplastin time, $\mathrm{ICH}$, intracranial hemorrhages) 
the studies discussed above is not, however, different from our previous ECMO patients in whom we did not see unusually high bleeding complications. It is therefore plausible that mechanisms other than anticoagulation per se could also be at play. It has been reported that COVID-19 nonsurvivors have a far higher incidence of disseminated intravascular coagulation. ${ }^{28}$ Fibrinolysis and associated drop in fibrinogen could potentially be responsible for bleeding. It remains to be seen if fibrinogen replacement could prevent the bleeding complications. ${ }^{29}$ It has now been well established that COVID-19 uses angiotensin-converting enzyme 2 (ACE2) receptors to infect the pneumocytes, but these receptors are widely present in the endothelium throughout the body including the brain. The neurotropic behavior of COVID-19 facilitated by ACE2 expression on neurovascular endothelium and or dysregulated vascular tone due to drop in ACE2 and unopposed action of angiotensin-II (AT-II) may also be responsible for hemorrhagic strokes. ${ }^{30,31}$ Having said that, all four patients with intracranial bleed had fibrinogen $>1.5 \mathrm{~g} / \mathrm{L}$ and none had systolic or diastolic hypertension in the 72 hours leading up to the bleed.

Sixth, there is some evidence that putting many of these patients on ECMO much earlier in the disease could have saved more lives. In a series of 27 patients from New York, where a much lower threshold for ECMO initiation was used (PF ratio $<150 \mathrm{~mm} \mathrm{Hg}$ or $\mathrm{pH}<7.25$ with $\mathrm{paCO}_{2}$ greater than $8 \mathrm{kPa}$ ), a $96.3 \%$ survival rate was reported. Many of our patients were referred late to our facility and others received many proning sessions before going on ECMO (median 62 hours, IQR 28-80). This could also explain the longer days on ECMO in our series (median 32.5 days in survivors, IQR 15-66), which was much higher than 14 days in one series ${ }^{24}$ and 20 days in the French series. ${ }^{6}$ Further research should explore what qualifies a satisfactory or sustained response to prone positioning and when further proning sessions should be abandoned in favor of ECMO.

Finally, three of our patients were weaned from ECMO after 6 weeks and one of them was weaned after 12 weeks. This observation again highlights the time needed for lung recovery in viral pneumonias and especially COVID-19, which could occur after several weeks or months. Lung transplantation has been considered as a therapeutic option in patients with severely injured lungs after COVID-19 disease. Although some experts have suggested that we should consider transplantation after just 4-6 weeks of illness, ${ }^{32}$ this is very contentious as the 5 -year survival after lung transplant has not greatly improved over the years and as shown in our series, lung recovery can be complete even after months of illness. Hence, a more conservative approach that avoids lung transplants may be preferred. Further data should explore determining the definition of meaningful lung recovery and who might and might not require a transplant.

\section{OrCID}

Vivek Kakar $\odot$ https://orcid.org/0000-0001-6353-3283 Anita North ๑ https://orcid.org/0000-0003-3138-2833 Gurjyot Bajwa 이ths://orcid.org/0000-0001-9434-8072 Nuno Raposo @ https://orcid.org/0000-0001-9931-8905 Praveen Kumar G @ https://orcid.org/0000-0002-2875-5726

\section{References}

1. Ziehr DR, Alladina J, Petri CR, Maley JH, Moskowitz A, Medoff BD, et al. Respiratory pathophysiology of mechanically ventilated patients with COVID-19: a cohort study. Am J Respir Crit Care Med 2020;201(12):1560-1564. DOI: 10.1164/rccm.202004-1163LE.

2. Gattinoni L, Coppola S, Cressoni M, Busana M, Rossi S, Chiumello D. COVID-19 does not lead to a "typical" acute respiratory distress syndrome. Am J Respir Crit Care Med 2020;201(10):1299-1300. DOI: 10.1164/rccm.202003-0817LE.

3. Roberts CM, Levi M, McKee M, Schilling R, Lim WS, Grocott MPW. COVID-19: a complex multisystem disorder. Br J Anaesth 2020;125(3):238-242. DOI: 10.1016/j.bja.2020.06.013.

4. Coppo A, Bellani G, Winterton D, Di Pierro M, Soria A, Faverio P, et al. Feasibility and physiological effects of prone positioning in non-intubated patients with acute respiratory failure due to COVID-19 (PRON-COVID): a prospective cohort study. Lancet Respir Med 2020;8(8):765-774. DOI: 10.1016/S2213-2600(20)30268-X.

5. Mittermaier M, Pickerodt $P$, Kurth F, de Jarcy LB, Uhrig A, Garcia $C$, et al. Evaluation of PEEP and prone positioning in early COVID-19 ARDS. EClinicalMedicine 2020;28:100579. DOI: 10.1016/ j.eclinm.2020.100579.

6. Schmidt M, Hajage D, Lebreton G, Monsel A, Voiriot G, Levy D, et al. Extracorporeal membrane oxygenation for severe acute respiratory distress syndrome associated with COVID-19: a retrospective cohort study. Lancet Respir Med 2020;8(11):1121-1131. DOI: 10.1016/S22132600(20)30328-3.

7. Barbaro RP, MacLaren G, Boonstra PS, Iwashyna TJ, Slutsky AS, Fan E, et al. Extracorporeal membrane oxygenation support in COVID-19: an international cohort study of the Extracorporeal Life Support Organization registry. Lancet 2020;396(10257):1071-1078. DOI: 10.1016/S0140-6736(20)32008-0.

8. Falcoz PE, Monnier A, Puyraveau M, Perrier S, Ludes PO, Olland A, et al. Extracorporeal membrane oxygenation for critically ill patients with COVID-19-related acute respiratory distress syndrome: worth the effort? Am J Respir Crit Care Med 2020;202(3):460-463. DOI: 10.1164/ rccm.202004-1370LE.

9. Agerstrand C, Dubois R, Takeda K, Uriel N, Lemaitre P, Fried J, et al. Extracorporeal membrane oxygenation for coronavirus disease 2019: crisis standards of care. ASAIO J 2021;67(3):245-249. DOI: 10.1097/ MAT.0000000000001376.

10. Kon ZN, Smith DE, Chang SH, Goldenberg RM, Angel LF, Carillo JA, et al. Extracorporeal membrane oxygenation support in severe COVID-19. Ann Thorac Surg 2021;111(2):537-543. DOI: 10.1055/s-0040-1721487.

11. Waite AAC, Hamilton DO, Pizzi R, Ageno W, Welters ID. Hypercoagulopathy in severe COVID-19: implications for acute care. Thromb Haemost 2020;120(12):1654-1667. DOI: 10.1055/s-00401721487.

12. Sadeghipour P, Talasaz AH, Rashidi F, Sharif-Kashani B, Beigmohammadi MT, Farrokhpour M, et al. Effect of intermediatedose vs standard-dose prophylactic anticoagulation on thrombotic events, extracorporeal membrane oxygenation treatment, or mortality among patients with COVID-19 admitted to the intensive care unit: the INSPIRATION randomized clinic. JAMA 2021;325(16):1620-1630. DOI: 10.1001/jama.2021.4152.

13. Shah A, Donovan K, McHugh A, Pandey M, Aaron L, Bradbury CA, et al. Thrombotic and haemorrhagic complications in critically ill patients with COVID-19: a multicentre observational study. Crit Care 2020;24(1):561. DOI: 10.1186/s13054-020-03260-3.

14. Panagiotis Margos N, Stylianos Meintanopoulos A, Filioglou D, Ellul J. Intracerebral hemorrhage in COVID-19: a narrative review. J Clin Neurosci 2021;89:271. DOI: 10.1016/j.jocn.2021.05.019.

15. Godier A, Clausse D, Meslin S, Bazine M, Lang E, Huche F, et al. Major bleeding complications in critically ill patients with COVID-19 pneumonia. J Thromb Thrombolysis 2021;52(1):18-21. DOI: 10.1007/ s11239-021-02403-9.

16. Combes A, Hajage D, Capellier G, Demoule A, Lavoué S, Guervilly $C$, et al. Extracorporeal membrane oxygenation for severe acute respiratory distress syndrome. N Engl J Med 2018;378(21):1965-1975. DOI: 10.1056/NEJMoa1800385. 
17. Extracorporeal Life Support Organization (ELSO) ELSO Registry Data Definitions. 2018. Available from: www.ELSO.org.

18. Full COVID-19 Registry Dashboard. 2021. Available from: https:// www.elso.org/Registry/FullCOVID19RegistryDashboard.aspx.

19. Tatooles AJ, Mustafa AK, Alexander PJ, Joshi DJ, Tabachnick DR, Cross $C A$, et al. Extracorporeal membrane oxygenation for patients with COVID-19 in severe respiratory failure. JAMA Surg 2020;155(10):990992. DOI: 10.1001/jamasurg.2020.3950.

20. Arabi YM, Mandourah Y, Al-Hameed F, Sindi AA, Almekhlafi GA, Hussein MA, et al. Corticosteroid therapy for critically ill patients with middle east respiratory syndrome. Am J Respir Crit Care Med 2018;197(6):757-767. DOI: 10.1164/rccm.201706-1172OC.

21. Lee N, Chan PKS, Hui DSC, Rainer TH, Wong E, Choi KW, et al. Viral loads and duration of viral shedding in adult patients hospitalized with influenza. J Infect Dis 2009;200(4):492-500. DOI: 10.1086/600383.

22. RECOVERY Collaborative Group; Horby P, Lim WS, Emberson JR, Mafham M, Bell JL, Linsell L, et al. Dexamethasone in hospitalized patients with Covid-19. N Engl J Med 2021;384(8):693-704. DOI: 10.1056/NEJMoa2021436.

23. Schmidt M, Chommeloux J, Frere C, Hekimian G, Combes A. Overcoming bleeding events related to extracorporeal membrane oxygenation in COVID-19-authors' reply. Lancet Respir Med 2020;8(12):e89. DOI: 10.1016/S2213-2600(20)30468-9.

24. Zhang J, Merrick B, Correa GL, Camporota L, Retter A, Doyle A, et al. Veno-venous extracorporeal membrane oxygenation in coronavirus disease 2019: a case series. ERJ Open Res 2020;6(4):00463-2020. DOI: 10.1183/23120541.00463-2020.

25. Fletcher-Sandersjöö A, Thelin EP, Bartek J, Broman M, Sallisalmi M, Elmi-Terander $A$, et al. Incidence, outcome, and predictors of intracranial hemorrhage in adult patients on extracorporeal membrane oxygenation: a systematic and narrative review. Front Neurol 2018;9:548. DOI: 10.3389/fneur.2018.00548.

26. Luyt CE, Bréchot N, Demondion P, Jovanovic T, Hékimian G, Lebreton G, et al. Brain injury during venovenous extracorporeal membrane oxygenation. Intensive Care Med 2016;42(5):897-907. DOI: 10.1007/ s00134-016-4318-3.

27. Le Guennec L, Cholet $C$, Huang F, Schmidt M, Bréchot N, Hékimian $\mathrm{G}$, et al. Ischemic and hemorrhagic brain injury during venoarterialextracorporeal membrane oxygenation. Ann Intensive Care 2018;8(1):129. DOI: 10.1186/s13613-018-0475-6.

28. Tang N, Li D, Wang X, Sun Z. Abnormal coagulation parameters are associated with poor prognosis in patients with novel coronavirus pneumonia. J Thromb Haemost 2020;18(4):844-847. DOI: 10.1111/ jth.14768.

29. Paper: fibrinogen replacement underutilization in ECMO. 2021. Available from: https://ash.confex.com/ash/2020/webprogram/ Paper142812.html.

30. Zhou Z, Kang H, Li S, Zhao X. Understanding the neurotropic characteristics of SARS-CoV-2: from neurological manifestations of COVID-19 to potential neurotropic mechanisms. J Neurol 2020;267(8):2179-2184. DOI: 10.1007/s00415-020-09929-7.

31. Bermejo-Martin JF, Almansa R, Torres A, Gonzalez-Rivera M, Kelvin DJ. Covid-19 as a cardiovascular disease: the potential role of chronic endothelial dysfunction. Cardiovasc Res 2020;116(10):E132-E133. DOI: 10.1093/cvr/cvaa140.

32. Cypel M, Keshavjee $\mathrm{S}$. When to consider lung transplantation for COVID-19. Lancet Respir Med 2020;8(10):944-946. DOI: 10.1016/ S0140-6736. 